\title{
Degradation of Titanium Sintered with Magnesium: Effect of Hydrogen Uptake
}

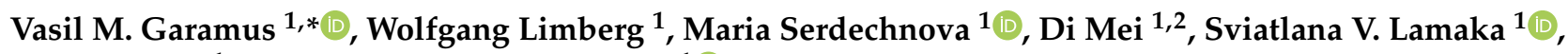 \\ Thomas Ebel ${ }^{1}$ and Regine Willumeit-Römer ${ }^{1}$ (D) \\ 1 Helmholtz-Zentrum Geesthacht: Centre for Materials and Coastal Research, 21502 Geesthacht, Germany; \\ wolfgang.limberg@hzg.de (W.L.); maria.serdechnova@hzg.de (M.S.); di.mei@hzg.de (D.M.); \\ sviatlana.lamaka@hzg.de (S.V.L.); thomas.ebel@hzg.de (T.E.); regine.willumeit@hzg.de (R.W.-R.) \\ 2 School of Materials Science and Engineering \& Henan Key Laboratory of Advanced Magnesium Alloy, \\ Zhengzhou University, Zhengzhou 450001, China \\ * Correspondence: vasyl.haramus@hzg.de; Tel.: +49-4152-871915
}

Citation: Garamus, V.M.; Limberg, W.; Serdechnova, M.; Mei, D.;

Lamaka, S.V.; Ebel, T.;

Willumeit-Römer, R. Degradation of Titanium Sintered with Magnesium: Effect of Hydrogen Uptake. Metals 2021, 11, 527. https://doi.org/ $10.3390 / \operatorname{met} 11040527$

Academic Editor: Javier Aldazabal

Received: 26 February 2021

Accepted: 18 March 2021

Published: 24 March 2021

Publisher's Note: MDPI stays neutral with regard to jurisdictional claims in published maps and institutional affiliations.

Copyright: (C) 2021 by the authors Licensee MDPI, Basel, Switzerland. This article is an open access article distributed under the terms and conditions of the Creative Commons Attribution (CC BY) license (https:// creativecommons.org/licenses/by/ $4.0 /)$.

\begin{abstract}
Multifunctional materials based on a combination of permanent and degradable metals open new perspectives for medical implants combining osseoconductivity and drug-delivery functions which can significantly decrease the number of implants' revision. In this work, hybrid magnesium-titanium materials were produced via sintering, and the properties of the permanent titanium component before and after the degradation of the temporary magnesium part were evaluated. The changes of chemical composition and mechanical parameters were determined. Loading of hydrogen into the titanium part at room temperature was observed, which deteriorated the mechanical characteristics but could also simultaneously improve the biocompatibility of the permanent titanium implant. The control of degradation of the magnesium part and the modification of the titanium part are required for the development of partly degradable hybrid implants.
\end{abstract}

Keywords: titanium; magnesium degradation; hydrogen uptake; titanium hydrides; mechanical properties; hydrogen embrittlement

\section{Introduction}

Metallic implants are generally applied in orthopedic and craniofacial surgery, dental practice and as vascular stents [1]. Titanium and titanium alloys, due to their high strength, low density, high corrosion resistance, inertness to body environment and excellent integrity to the bone are widely used from hip to wrist applications and as bone fixation materials [2]. In vitro studies of titanium foams and human osteoblasts showed that cells differentiate into mature bone cells with osteoinductive properties, which makes titanium unique among metals [3]. Magnesium, as a biodegradable metallic material, offers additional opportunities due to its biocompatibility, resorbability and antibacterial properties [4]. Controlled degradation of magnesium implants is already used in modern medicine (confirmed by recent meta-analysis studies of clinical trials [5]), with growth potential as the role of $\mathrm{Mg}$ in bone-healing becomes clearer [6].

It is quite natural that there are significant efforts to combine the best properties of both materials (Mg and Ti), aiming to overcome well-known limitations of metallic implants, such as the stress shielding effect [7] and the susceptibility to infections [8]. The hybrid implant material, which consists of permanent $\mathrm{Ti}$ and temporary Mg parts (bimetallic couples), can be used in the cases when high strength of titanium and bone stimulation by degradation of magnesium are required and/or only partial bone remodelling is expected, as in the case of revision surgery [9]. These hybrid materials enable also the design of drug-delivery devices, i.e., loading the permanent and/or the temporary parts with drugs.

Application of magnesium films on porous titanium and the local release of magnesium ions from the implant surfaces were reported to enhance implant retention, osteogen- 
esis and angiogenesis [10-12]. The development of a hybrid fixation system which includes the combination of $\mathrm{Mg}$ and Ti screws instead of only Ti screws has been announced [13,14]. It was possible not only to reduce the number of screw removals after healing but also to improve bone regeneration, suppress bone resorption and induce blood vessel formation combined with an antibacterial effect. In a rabbit model, the failure load has increased by $30 \%$ after 12 weeks of application [14].

There are special requirements for the connection combining Ti and Mg parts: it has to be strong enough for implant positioning in the body and, in case of titanium alloys, the possible diffusion of alloying elements from the Ti part into the Mg part should be negligible. The low solubility between $\mathrm{Ti}$ and $\mathrm{Mg}$ is a good presumption for the latter demand but may hinder a tight connection on an atomic scale [15]. However, studies on porous $\mathrm{Ti} / \mathrm{Mg}$ composites where $\mathrm{Mg}$ plays a role of the degradable anodic part, which gives space for the ingrowing cells, show that the cohesion between $\mathrm{Mg}$ and Ti is sufficient for proper mechanical characteristics [16].

Another strong concern on simultaneous use of $\mathrm{Ti}$ and $\mathrm{Mg}$ is the large difference in electrochemical potential of $\mathrm{Mg}$ and $\mathrm{Ti}$, which could lead to accelerated degradation of $\mathrm{Mg}$. In vivo and in vitro studies demonstrated that the distance of $5 \mathrm{~mm}$ between $\mathrm{Mg}$ and Ti parts is critical for the degradation of Mg. Most probably, blood vessels form a good electrical connection which enhances degradation of $\mathrm{Mg}$ [17].

To overcome increased corrosion, it is possible to use a polymeric layer between $\mathrm{Mg}$ and Ti parts as it has been applied in a hybrid fixation system [13]. Another possibility is the selection of suitable $\mathrm{Mg}$ alloys like aluminum- and zinc-containing AZ alloys that still show an acceptable degradation rate in contact with titanium alloys $[18,19]$. However, the presence of aluminum limits their application as implant material.

In the above-mentioned investigations, it was postulated that the Ti-material is unaffected by $\mathrm{Mg}$ degradation. To investigate whether this assumption is justifiable, in the present study we have constructed Ti-Mg-alloy and Ti64-Mg-alloy (here: Ti64 defined as Ti-6Al-4V alloy) hybrid specimens via a powder metallurgy approach. Powder metallurgy technologies based on sintering, like metal injection molding (MIM) are frequently used to produce specimens with variable shape and mechanical characteristics and are also applied for Ti and its alloys [20,21]. The sintering of Mg powder is more challenging [22,23] due to higher melting temperature of $\mathrm{Mg}$ oxide layer than bulk Mg. However, the addition of a small amount of Ca helps destroy the surface oxide layer of the Mg particles, which otherwise hinders sintering. Principally, sintering gives a quite good mechanical connection between $\mathrm{Ti}$ and $\mathrm{Mg}$ and could be used for the production of implants [24]. However, the effect of degradation on the Ti-material has not yet been investigated. In the present work, the degradation of the $\mathrm{Mg}$ part of the hybrid specimens in saline solution was performed, and related possible changes in composition, phase structure and mechanical properties of Ti part were studied. Significant changes of the titanium parts have been observed, which should be taken into account in further simultaneous applications of $\mathrm{Mg}$ and Ti implants and can be used for optimizing the properties of future implants.

\section{Materials and Methods}

\subsection{Preparation of Specimens}

A rod of Titanium Grade 2 (ASTM B348) was obtained from Ankuro Int. (Rostock, Germany). This rod (with diameter $10 \mathrm{~mm}$ ) was cut into discs with the thickness of $1.5 \mathrm{~mm}$ by using a diamond saw. Mg- $0.6 \mathrm{Ca}$ alloy was produced by casting and subsequent extrusion with a speed of $4.4 \mathrm{~m} / \mathrm{s}$. Mg-0.6wt.\%Ca discs of $9 \mathrm{~mm}$ diameter and $1.5 \mathrm{~mm}$ thickness were machined from the rod. Ti and $\mathrm{Mg}$ discs were cleaned and put pairwise into the sintering furnace (RRO 350-900, MUT Advanced Heating, Jena, Germany) for $8 \mathrm{~h}$ at $640{ }^{\circ} \mathrm{C}$ under $\mathrm{Ar}$ atmosphere.

For tensile test measurements, dog-bone shaped samples of Ti64 were manufactured via the metal injection molding (MIM) method and sintered (see the Supplementary Materials). The middle part of the obtained Ti64 dog-bone samples was covered with $\mathrm{Mg}-0.6 \mathrm{Ca}$ 
also using MIM (Figure 1) and sintered (see the Supplementary Materials). The thickness of the $\mathrm{Mg}-0.6 \mathrm{Ca}$ feedstock layer in the middle part before sintering was $5 \mathrm{~mm}$.

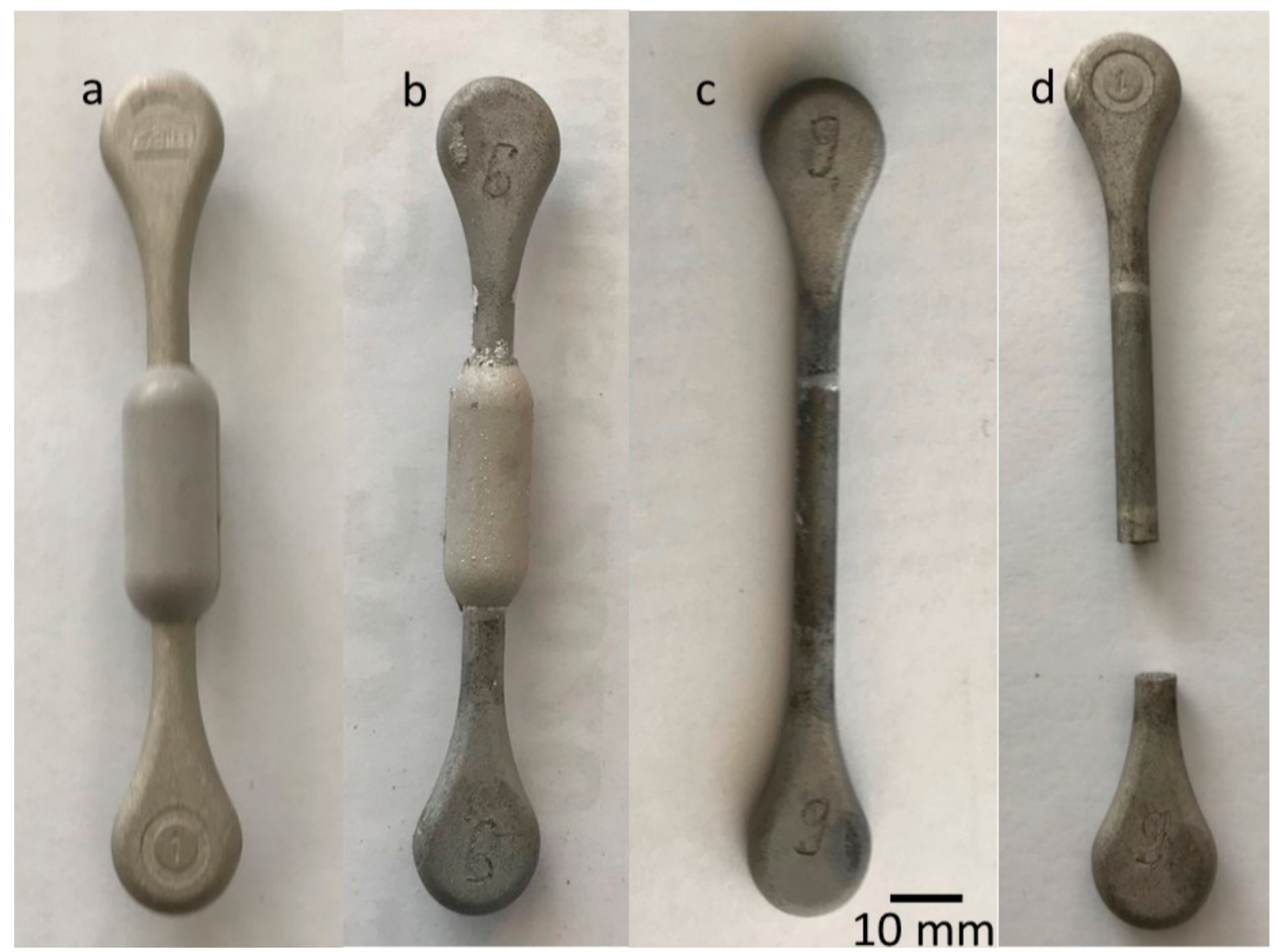

Figure 1. Dog-bone-shape tensile test samples of hybrid Ti64/Mg-0.6Ca after metal injection molding (MIM) production (a), sintering (b), corrosion (c) of $\mathrm{Mg}$ and tensile test (d).

\subsection{Characterisation}

Corrosion experiments were performed in $0.9 \mathrm{wt} . \% \mathrm{NaCl}$ solution at room temperature, and the corrosion rate was followed by the hydrogen evolution method. Corrosion products were removed from $\mathrm{Mg}$ samples by washing them in a $200 \mathrm{~g} \cdot \mathrm{L}^{-1}$ solution of chromic acid for $10 \mathrm{~min}$. High-performance micro-X-ray fluorescence spectrometer (M4 TORNADO, Bruker Nano, Berlin, Germany) was used to verify the full removal of Mg products from the Ti surface.

Determination of chemical composition (contents of $\mathrm{O}, \mathrm{N}$ and $\mathrm{H}$ ) in the titanium part before and after degradation of $\mathrm{Mg}$ was done via inert gas fusion technique using a LECO apparatus (ONH836, LECO, St Joseph, MI, USA). For this, Ti discs and Ti64 dog-boneshape samples were cut into pieces of approximately $50 \mathrm{mg}$ each by using a diamond saw and finally cleaned. Results were obtained as average value of three pieces, and the measurement was repeated for three different Ti discs.

Phase identification was performed by grazing incidence X-ray diffraction (GIXRD) (see the Supplementary Materials) using a Bruker D8 Advance X-ray diffractometer (Bruker AXS, Karlsruhe, Germany).

Tensile tests were performed according to DIN EN ISO 6892-1:2009 B on a universal materials-testing machine (ZwickRoell, Ulm, Germany).

Images of the Ti cross section were recorded using scanning electron microscopy (VEGA3 TESCAN-15kV, TESCAN, Kohoutovice, Czech Republic, see the Supplementary Materials). 


\section{Results}

After sintering heat treatment of the $\mathrm{Mg}-0.6 \mathrm{Ca} / \mathrm{Ti}$ discs at $640{ }^{\circ} \mathrm{C}$ for $8 \mathrm{~h}$ a tight connection was obtained between the two materials (Figure 2) which was expected from previous investigations [24]. For the corrosion experiments, $\mathrm{Mg}-0.6 \mathrm{Ca} / \mathrm{Ti}$ couples were placed into saline solution $(0.9 \mathrm{wt} . \% \mathrm{NaCl})$. The degradation of the $\mathrm{Mg}$-alloy was very fast (Figure 2). In contrast to the uncoupled specimen, the Mg-alloy part was completely dissolved after only two days of immersion. Afterwards, there was no additional $\mathrm{H}_{2}$ evolved. This indicates that $\mathrm{Mg}$ was fully dissolved based on the following reaction:

$$
\mathrm{Mg}+2 \mathrm{H}_{2} \mathrm{O} \rightarrow \mathrm{Mg}(\mathrm{OH})_{2}+\mathrm{H}_{2} \uparrow
$$

This is in agreement with recent studies of $\mathrm{Mg}$ (-alloy)/Ti64 composites where pure $\mathrm{Mg}$ and WE alloys showed very high degradation rates [18] with complete degradation in 1-2 days. The amount of released $\mathrm{H}_{2}(\sim 800 \mathrm{~mL})$ corresponded to the total mass of $\mathrm{Mg}$ $(0.819 \mathrm{~g})$, according to Equation (1).
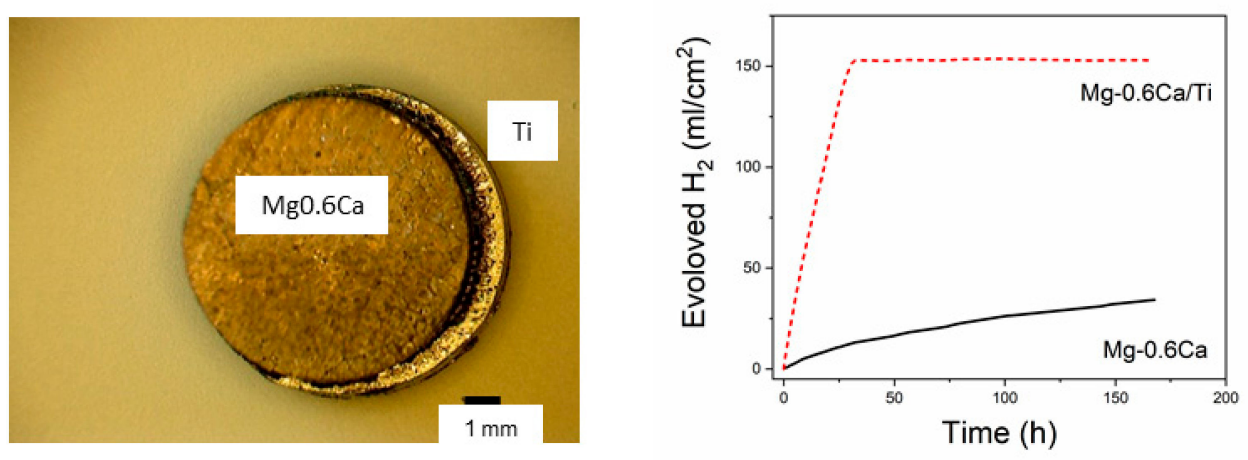

Figure 2. Photo of $\mathrm{Mg}-0.6 \mathrm{Ca}$ and $\mathrm{Ti}$ plates after heat treatment at $640{ }^{\circ} \mathrm{C}$ for $8 \mathrm{~h}$ (left) and the evaluation of $\mathrm{H}_{2}$ for $\mathrm{Mg}-0.6 \mathrm{Ca} / \mathrm{Ti}$ couple in saline solutions $(0.9 \mathrm{wt} \% \mathrm{NaCl})$ and, in comparison, $\mathrm{Mg}-0.6 \mathrm{Ca}$ alone (right).

After corrosion experiments, the Ti plates were cleaned by chromic acid from corrosion products of $\mathrm{Mg}$. There were no traces of $\mathrm{Mg}$ on the Ti plates detectable by $\mathrm{X}$-ray fluorescence analysis. On the other hand, the Ti plate partially changed the color (Figure 3) which can typically be connected to a variation of the oxide layer thickness. The comparison of the weight of the titanium plates before and after corrosion of the Mg-part pointed to a weight gain (Figure 4). Here, five Ti discs have been analyzed. It meant that titanium absorbed some elements during corrosion of Mg. However, the error bars were rather high, so the effect appeared to be small. In Figure 4, a comparison is shown to Ti samples which have been treated in a similar way (exposition in saline solution and chromic acid treatment), but without connection to $\mathrm{Mg}$.
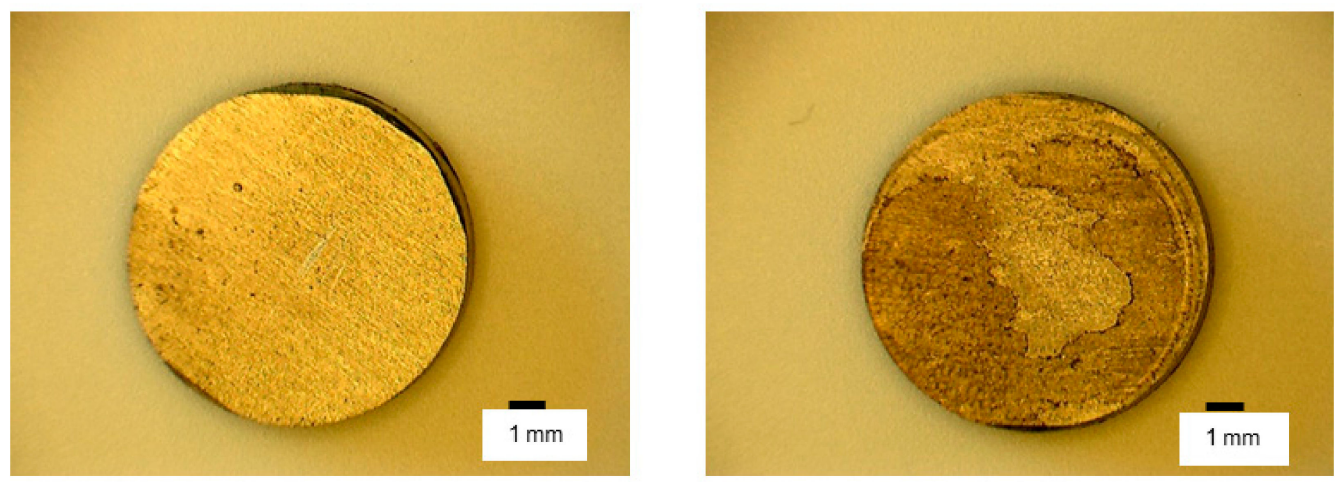

Figure 3. Photos of Ti plates before (left) and after (right) corrosion of $\mathrm{Mg}$. 


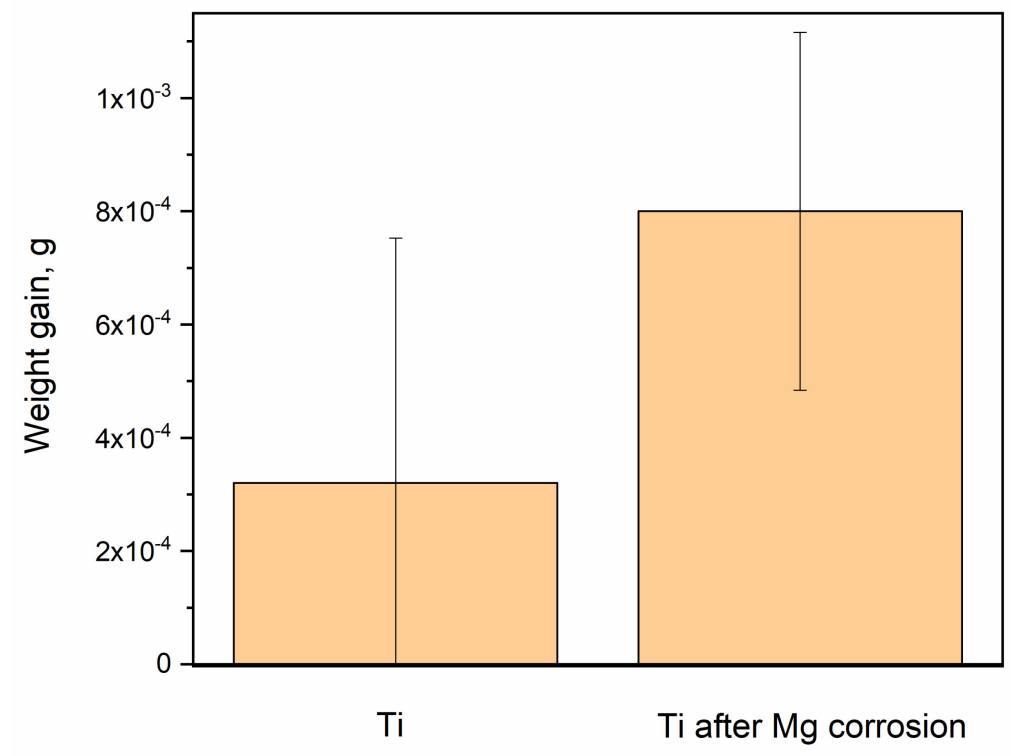

Figure 4. The change of weight of the Ti plate after exposition to saline solution and subsequent chromic acid treatment. Left bar (Ti): without coupled $\mathrm{Mg}$; right bar (Ti after $\mathrm{Mg}$ corrosion): with coupled Mg. Numbers are average values of five discs.

For chemical analysis, the samples after degradation of $\mathrm{Mg}$ were cut into smaller pieces ( $\sim 50 \mathrm{mg}$ ) and compared to uncoupled Ti after the same treatment. The chemical analysis showed that there was a small variation of concentration in $\mathrm{O}$ and $\mathrm{N}$ and a significant increase in the content of $\mathrm{H}$ (Figure 5).

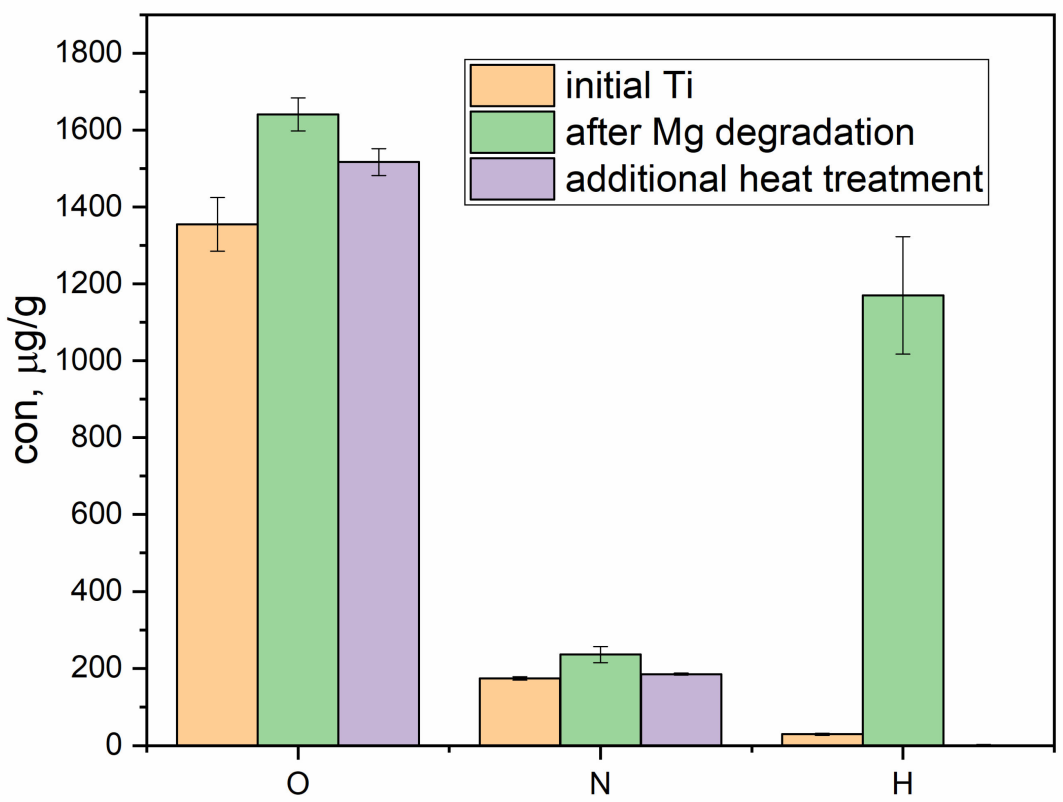

Figure 5. Content of $\mathrm{H}, \mathrm{N}$ and $\mathrm{O}$ in titanium part: initial $\mathrm{Ti}$, after degradation of $\mathrm{Mg}$ alloy sintered with $\mathrm{Ti}$ and after additional heat treatment at $1100{ }^{\circ} \mathrm{C}$ in a vacuum.

It should be pointed out that such a significant increase of $\mathrm{H}$ content from below $50 \mu \mathrm{g} / \mathrm{g}$ to above $1000 \mu \mathrm{g} / \mathrm{g}$ took place at room temperature and was the direct result of $\mathrm{Mg}$ corrosion. Additional tests have been performed to check out other possible sources (chromic acid treatment, simultaneous heating of $\mathrm{Ti}$ and $\mathrm{Mg}$ ) of $\mathrm{H}$ loading within the applied process. However, the results were negative and those factors could not have caused hydrogen absorption by Ti. By application of high temperatures $\left(1100{ }^{\circ} \mathrm{C}\right)$ and 
vacuum for $2 \mathrm{~h}$, the loaded hydrogen was released again, so the concentration decreased below $1 \mu \mathrm{g} / \mathrm{g}$ (Figure 5). Thus, it was proven that indeed hydrogen was loaded into titanium at room temperature, which is typically not expected because of the inherent dense and protective oxide layer on Ti.

It is quite important to know how the hydrogen was distributed in Ti. SEM images showed only some dark regions on the surface of the Ti plates which could be the location of $\mathrm{H}$ loading (see the Supplementary Materials, Figure S1) and EDX is not sensitive to low weight elements such as $\mathrm{H}$. To overcome this problem, we have performed grazing incidence X-ray diffraction. Figure 6 presents the comparison of GIXRD patterns of initial $\mathrm{Ti}$ and Ti coupled with $\mathrm{Mg}$ after degradation of $\mathrm{Mg}$. The initial titanium sample showed almost only peaks (100), (002), (101), (102), (110), (103), (112), (201) of crystalline $\alpha \mathrm{Ti}$ in hexagonal phase P63/mmc a = 2.9504 $\AA, \mathrm{c}=4.6933 \AA$ (PDF 03-065-3362, Data 2015). In contrast, the coupled Ti sample after magnesium degradation showed peaks of Ti (similar to initial Ti) and additional peaks (111), (200), (220), (311), (222) from $\mathrm{TiH}_{2}$ cubic phase (fcc) $\mathrm{a}=4.42 \AA$ (PDF 00-009-0371, Data 2015). The results suggest that hydrogen emerging during $\mathrm{Mg}$ degradation saturates the Ti-phase and leads to the formation of hydrides. Again, it should be mentioned that the transformation from pure hexagonal Ti phase to a mixture with the hydride phase takes place at room temperature. Industrially, a hydrogenation process is applied for some purposes. However, process temperatures in interval from $600{ }^{\circ} \mathrm{C}$ to $700{ }^{\circ} \mathrm{C}$ are usually required.

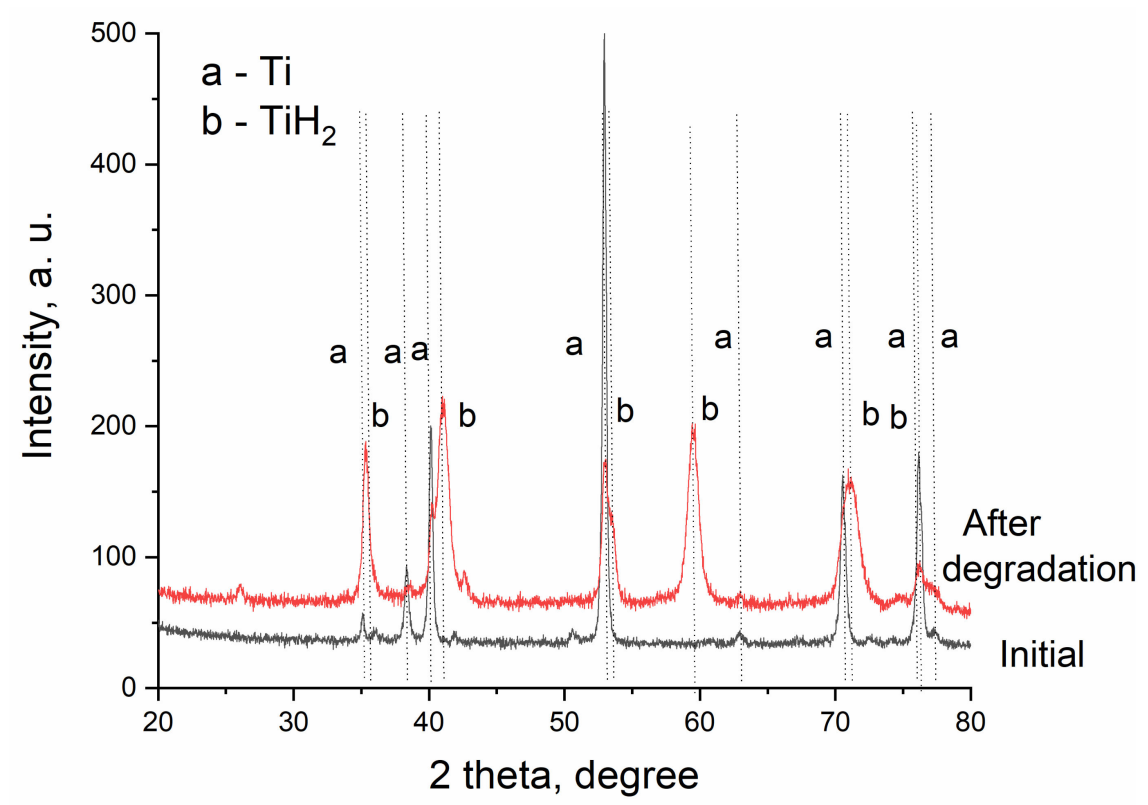

Figure 6. Grazing incidence X-ray diffraction (GIXRD) data of titanium plate and titanium plate sintered with $\mathrm{Mg}$ alloy after degradation of $\mathrm{Mg}$ alloy.

It is well-known that loading of a high amount of $\mathrm{H}$ in Ti and the formation of titanium hydrides change the mechanical properties of titanium parts rather drastically [25,26]. This might significantly affect the implant properties depending on the application. To check the evolution of mechanical properties with hydrogen uptake, we used the dogbone samples produced by MIM consisting of Ti64 and Mg-0.6Ca (Figure 1). Even if the corrosion properties of Ti and Ti64 are not absolutely identical [27] and Ti64 shows higher corrosion resistance in Ringer's artificial simulated body fluids, the basic results related to hydrogen uptake are not supposed to be affected in the frame of this study. After the same procedure of sintering heat treatment for the plates, tensile tests were performed after corrosion experiments in $0.9 \mathrm{wt} . \% \mathrm{NaCl}$ (Figure 1). They were compared with tensile tests on uncoupled sintered Ti64 specimens. As it can be seen in Figure 7, the uncoupled Ti64 sample showed elastic and plastic features with elongation to fracture up to $12 \%$. However, 
all hybrid samples after corrosion of Mg have been broken early within the elastic area. The location of fracture for all hybrid samples are not in the center, which is shown in Figure 1d. In the case of initial Ti64, the fracture was always in the center of the sample. Thus, by uptake of hydrogen, the ductility was completely lost. The average content of hydrogen in the titanium part of the dog-bone samples after degradation of $\mathrm{Mg}$ was approximately two times higher $(2130 \pm 98 \mu \mathrm{g} / \mathrm{g})$ than in the plate samples. This was probably related to the fact that the Mg part covered the Ti alloy part almost completely.

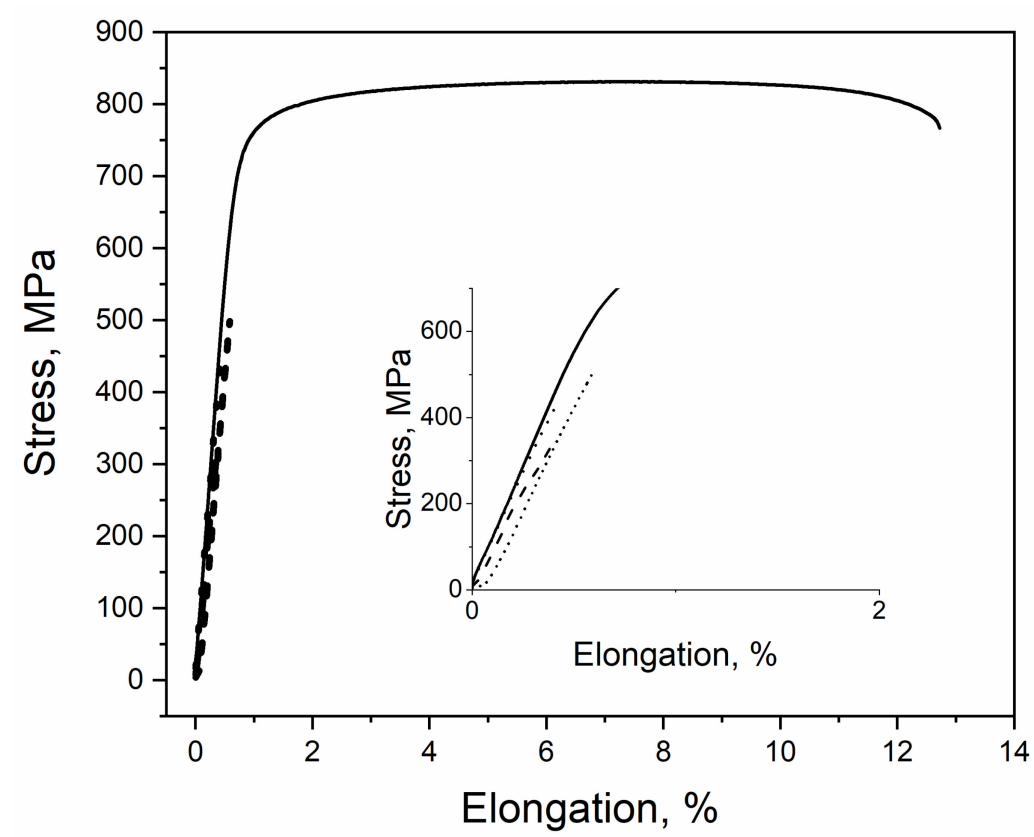

Figure 7. Results of tensile tests for initial Ti64 (solid line) and Ti64 sintered with Mg alloy (three samples) after Mg degradation (broken lines). Insert shows the elastic region of measurements. Measurements of initial Ti64 were repeated three times which showed the similar behavior in elastic and plastic regions. One curve is presented to keep the figure clear.

The locations of the fracture induced by the tensile test have been examined using SEM. For the initial sample (Figure 8, left) white and dark regions were visible very clearly, corresponding to $\beta$ (white)—high solubility of hydrogen, and $\alpha$ (dark)—low solubility of hydrogen phases. After corrosion of Mg (Figure 8, right) it appeared that the structure became finer, and the comparison with the pseudo-binary phase diagram of Ti64- $\mathrm{H}$ [28] indicated the transformation to $\alpha_{2}\left(\mathrm{TiAl}_{3}\right)$ and $\delta$ (highest solubility of hydrogen, $\left.\mathrm{TiH}_{2}\right)$ phases with visible boundaries of $\alpha / \beta$. This fully matches the results from the diffraction experiments.
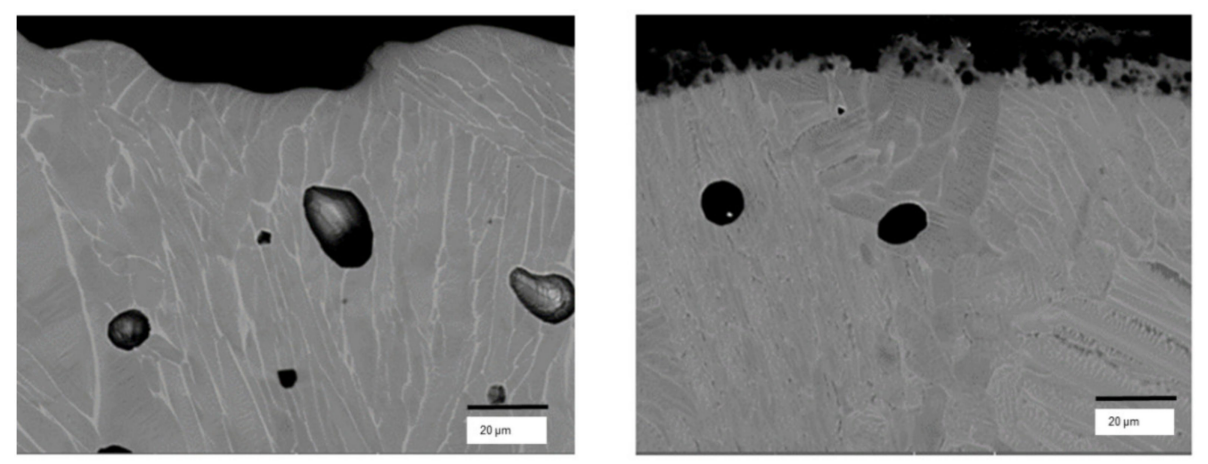

Figure 8. Scanning electron microscopy (SEM) micrographs of the fracture area of the initial Ti64 sample (left) and Ti64 sintered with $\mathrm{Mg}$ alloy after $\mathrm{Mg}$ degradation (right). 


\section{Discussion}

Any unintended changes observed in permanent implant materials are undesired. The variation of color and weight of the titanium part after degradation of magnesium should be taken with significant attention. The observed weight gain was connected with adsorption of hydrogen and the change of thickness of the titanium oxide layer, which causes the change of color.

Hydrogen is known for prompting embrittlement in most metallic materials. Pure titanium is less susceptible and shows good ductility for up 25 at.\% hydrogen [29]. In the present study, the estimated concentration of hydrogen (around 5-10 at.\%) should be below the limit mentioned above but infringing ASTM standards $(<150 \mathrm{ppm})$ for common Ti materials [30]. The tensile tests suggested that the actual amount of adsorbed hydrogen was higher than the plasticity limit for Ti64. Hydrogen forms mainly the hydride $\mathrm{TiH}_{2}$ (face centered cubic) which can be attributed to $\delta$ phase and usually it is observed for hydrogen loading into titanium at high temperatures $\left(\sim 750^{\circ} \mathrm{C}\right.$ [31]) or after cathodic hydrogenation at $80^{\circ} \mathrm{C}$ followed by thermal diffusion at $225^{\circ} \mathrm{C}$ [32]. According to the phase diagram of $\mathrm{Ti}-\mathrm{H}[33,34]$ the formation of $\delta$ phase takes place in the concentration range for $\mathrm{H}$ between 51.2 and 66.7 at.\%. As we did not perform homogenization of Ti and Ti64 parts, it is possible that at the surface of $\mathrm{Ti}$, the concentration of $\mathrm{H}$ was much higher than the average value obtained from chemical analysis.

The observed loading of a high amount of hydrogen into titanium takes place at room temperature under the immersion conditions and in presence of a high concentration of saline solution. The potentially important parameter is increased local pressure, it is known that by fast degradation of $\mathrm{Mg}$ in $\mathrm{Mg}$ /Ti-alloys composite, the gas pressure of formed hydrogen can be so high that it breaks the pre-sintered scaffold of titanium [18].

The other factor that could promote hydrogen absorption is a loss in stability of the oxide layer by presence and degradation of $\mathrm{Mg}$. It is possible that a part of oxygen migrates from the $\mathrm{TiO}_{2}$ layer to $\mathrm{Mg}$ because of the extremely high affinity of $\mathrm{Mg}$ to oxygen. This could also be a reason for the astonishingly good bonding by sintering between two metals with very low mutual solubility [24]. The destabilization of the oxide layer makes the surface of Ti easily accessible for $\mathrm{H}$, which is formed during degradation of $\mathrm{Mg}$. The most suitable place is the line where $\mathrm{Mg}$, Ti and the solvent are in contact. We should note that fracture of all samples after degradation of $\mathrm{Mg}$ took place in this part of sample (Figure 1d) and not in the middle as in the initial samples. Figure 9 shows that the profile of hydrogen absorption was not constant and showed two maxima ( 0 and $\sim 25 \mathrm{~mm})$ at the lines of $\mathrm{Mg}$, Ti and solvent contact. The maximum at $0 \mathrm{~mm}$ was significantly higher (here, fracture takes place). The reasons for higher maximum at $0 \mathrm{~mm}$ could be the higher local residual porosity of Ti64 and/or slightly higher amount of Mg.

The observed hydrogen loading can be explained by a metallic reduction reaction (MRR) which is widely used in material science [35]. According to the MRR mechanism, $\mathrm{TiO}_{2}$ is reduced to Ti by $\mathrm{Mg}$ that, in turn, oxidizes to $\mathrm{MgO}$ :

$$
2 \mathrm{Mg}+\mathrm{TiO}_{2} \rightarrow 2 \mathrm{MgO}+\mathrm{Ti}
$$

As a result, there is a direct contact between $\mathrm{Mg}$ and $\mathrm{Ti}$, which leads to transfer of electrons from $\mathrm{Mg}(\rightarrow \mathrm{MgO})$ to $\mathrm{TiO}_{2}(\rightarrow \mathrm{Ti})$ due to difference in electrochemical potential. The overall reaction of magnesium corrosion (1) consists of anodic magnesium oxidation Equation (3) and cathodic water reduction Equations (4) and (5)

$$
\mathrm{Mg}-2 e^{-} \leftrightarrow \mathrm{Mg}^{2+}
$$

First proposed by Höche et al. [36] and then proved by Density Functional Theory (DFT) calculations, it was shown that the Volmer-Heyrovsky reaction sequence is the predominant and most favorable, from the standpoint of energy barrier, pathway for hydrogen evolution during degradation of magnesium [37]. It starts with the water 
reduction step, according to Volmer, accompanied by adsorption of atomic hydrogen on magnesium surface:

$$
\mathrm{H}_{2} \mathrm{O}+e^{-} \leftrightarrow \mathrm{OH}^{-}+\mathrm{H}_{a d} \quad \text { (Volmer) }
$$

Adsorbed hydrogen reacts with a partially positive hydrogen atom of the water molecule in the Heyrovsky step:

$$
\mathrm{H}_{2} \mathrm{O}+e^{-}+\mathrm{H}_{a d} \leftrightarrow \mathrm{OH}^{-}+\mathrm{H}_{2} \quad \text { (Heyrovsky) }
$$

The next step is hydroxide formation:

$$
\mathrm{Mg}^{2+}+2 \mathrm{OH}^{-} \rightarrow \mathrm{Mg}(\mathrm{OH})_{2}
$$

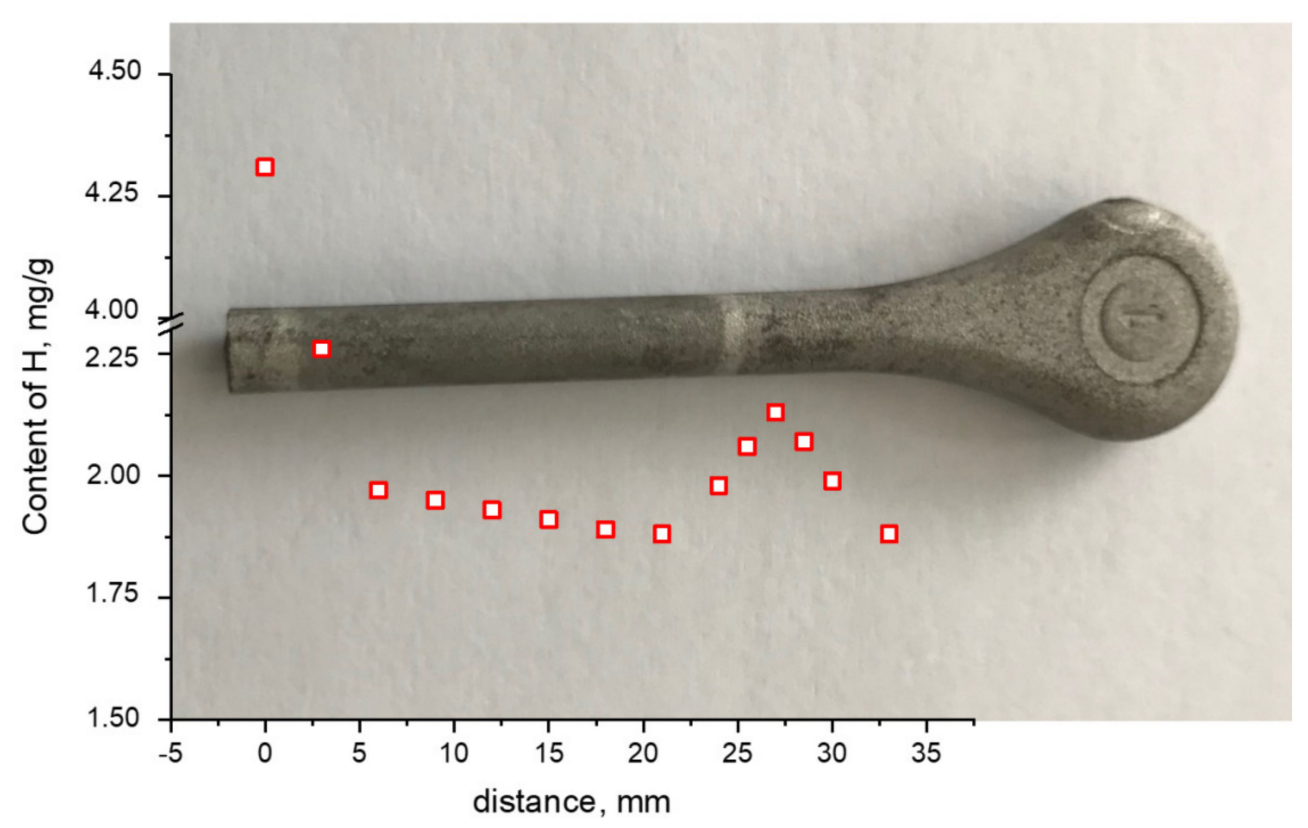

Figure 9. Concentration of absorbed $\mathrm{H}$ along the length of Ti64 dog-bone sample after degradation of $\mathrm{Mg}$ alloy.

The formed $\mathrm{Mg}(\mathrm{OH})_{2}$ is not fully passivating. It does not fully block the access of water and Cl-species to $\mathrm{MgO} / \mathrm{Mg}$ interface. Thus, corrosion of $\mathrm{Mg}$ continues even under the bulky layer of $\mathrm{Mg}(\mathrm{OH})_{2}$.

The $\mathrm{H}_{\mathrm{ad}}$ or $\mathrm{H}_{2}$ can be adsorbed by titanium given a high concentration of hydrogen, that is enough for the formation of hydrides following Equations (7) and (8).

$$
\begin{aligned}
\mathrm{Ti}+\mathrm{H}_{2} & \leftrightarrow \mathrm{TiH}_{2} \\
\mathrm{Ti}+2 \mathrm{H}_{a d} & \leftrightarrow \mathrm{TiH}_{2}
\end{aligned}
$$

The temperature of $640{ }^{\circ} \mathrm{C}$, at which Ti and $\mathrm{Mg}$ parts were kept to get good bonding, is quite important for the MRR process and most probably without bonding, the loading of $\mathrm{H}$ into Ti will be not so high.

From the other side, room temperature $\mathrm{Mg}$ reduction of $\mathrm{TiO}_{2}$ has been described recently [38]. It was shown that the contact between $\mathrm{Mg}$ and the oxide of $\mathrm{Ti}$ induces the direct transfer of electrons, which facilities the diffusion of oxygen from interfacial $\mathrm{TiO}_{2}$ and collecting $\mathrm{H}$ from the $\mathrm{HCl}$ solution. Theoretical calculations have shown that due to the connection of $\mathrm{Mg}$ and $\mathrm{TiO}_{2}$ the energy of reduction of $\mathrm{TiO}_{2}$ decreases by about $-1.27 \mathrm{eV}$, and this negative value reveals that the process of hydrogenation is exothermic [38]. In 
addition, the energy of formation of oxygen vacancies is more than $1 \mathrm{eV}$ lower for a $\mathrm{Mg}$ $\mathrm{TiO}_{2}$ connection in comparison with $\mathrm{TiO}_{2}$ standalone [38]. A similar process was possible in the present system (Figure 10). There is electron transfer from $\mathrm{Mg}$ to $\mathrm{TiO}_{2}$ which leads to enhanced hydrogenation. The pressure due to formation of $\mathrm{H}_{2}$ gas increases and plays an important role in hydrogenation, as it is shown in [38].

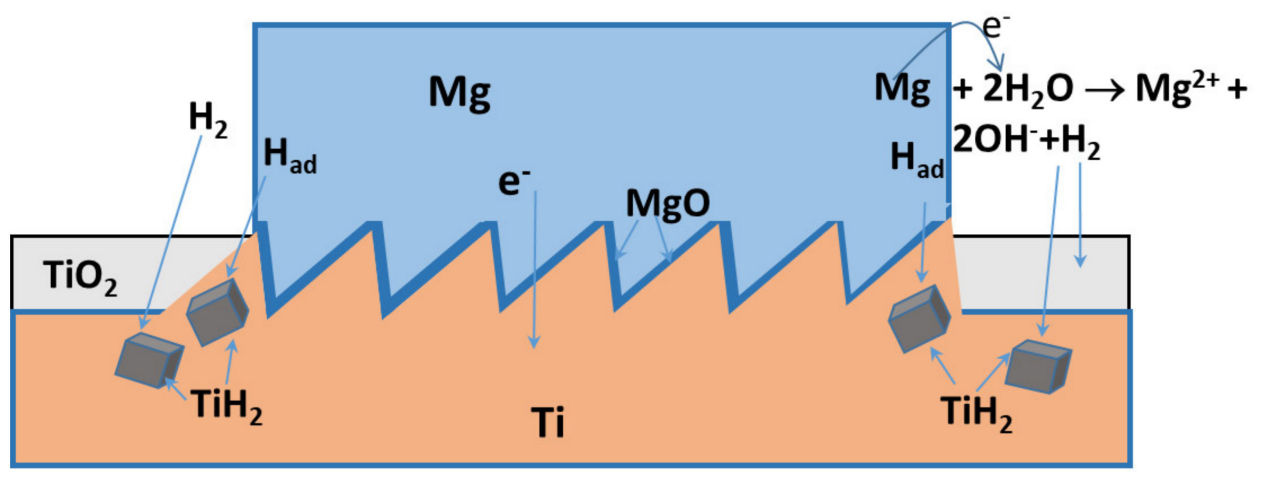

Figure 10. Possible scheme of loading of hydrogen $\left(\mathrm{H}_{\mathrm{ad}}\right.$ and $\left.\mathrm{H}_{2}\right)$ into the titanium part.

Formation of hydrides at the surface of titanium implants can be an important factor for improving biocompatibility and usually requires the etching in acids or application of electrical discharging [39]. It has been shown that treatment by concentrated sulfuric acid leads to the production of titanium hydrides with simultaneous increase of surface roughness and weight loss of titanium samples [40]. In the present study, the hydrides were obtained without such aggressive treatment. We propose that the degradation of $\mathrm{Mg}$ not only leads to improved bone growth due to the release of magnesium ions, but also potentially can improve biocompatibility of titanium implants via hydrides formation. Identified formation of hydrides provides additional explanation of enhanced biocompatibility of titanium implants after loading with magnesium, which was recently observed in many cases [10-12,41]. However, this aspect could not be investigated in the frame of this work.

\section{Conclusions}

In a saline solution, fast degradation of a Mg-part sintered to a Ti-part was promoted by galvanic coupling and accompanied by enhanced hydrogen evolution with further penetration of hydrogen into Ti at room temperature. High hydrogen content initiated the formation of titanium hydrides and a phase transformation from to $\alpha$ and $\beta$ to $\alpha_{2}$ and $\delta$ phases. Mechanical characteristics of Ti were strongly affected, i.e., the material became very brittle. Plastic elongation decreased from over $12 \%$ to below the detection limit. The formation of titanium hydrides (hydrogenation of titanium) by degradation of magnesium could substitute such complicate treatment as etching of titanium in acids that is applied to improve biocompatibility of Ti. Subsequent change of mechanical properties has to be carefully considered.

Supplementary Materials: The following are available online at https:/ /www.mdpi.com/2075-470 1/11/4/527/s1, Figure S1: Photos and SEM images of titanium plates. Details on sample preparation.

Author Contributions: Conceptualization, V.M.G., T.E. and R.W.-R.; investigation and data curation, W.L., M.S., D.M., S.V.L. and V.M.G.; writing-original draft preparation, V.M.G., T.E. and S.V.L.; supervision, T.E. and R.W.-R. All authors have read and agreed to the published version of the manuscript.

Funding: This research received no external funding.

Institutional Review Board Statement: Not applicable.

Informed Consent Statement: Not applicable. 
Data Availability Statement: The data presented in this study are available on request from the corresponding author. The data are not publicly available due to the data forms part of an ongoing study.

Conflicts of Interest: The authors declare no conflict of interests.

\section{References}

1. Chen, Q.; Thouas, G.A. Metallic implant biomaterials. Mater. Sci. Eng. R Rep. 2015, 87, 1-57. [CrossRef]

2. Navarro, M.; Michiardi, A.; Castano, O.; Planell, J.A. Biomaterials in orthopaedics. J. R. Soc. Interface 2008, 5, 1137-1158. [CrossRef]

3. Vandendolder, J.; Farber, E.; Spauwen, P.; Jansen, J. Bone tissue reconstruction using titanium fiber mesh combined with rat bone marrow stromal cells. Biomaterials 2003, 24, 1745-1750. [CrossRef]

4. Zhao, D.; Witte, F.; Lu, F.; Wang, J.; Li, J.; Qin, L. Current status on clinical applications of magnesium-based orthopaedic implants: A review from clinical translational perspective. Biomaterials 2017, 112, 287-302. [CrossRef] [PubMed]

5. Sukotjo, C.; Lima-Neto, T.J.; Santiago Junior, J.F.; Faverani, L.P.; Miloro, M. Is There a Role for Absorbable Metals in Surgery? A Systematic Review and Meta-Analysis of Mg/Mg Alloy Based Implants. Materials 2020, 13, 3914. [CrossRef] [PubMed]

6. Zhang, Y.; Xu, J.; Ruan, Y.C.; Yu, M.K.; O'Laughlin, M.; Wise, H.; Chen, D.; Tian, L.; Shi, D.; Wang, J.; et al. Implant-derived magnesium induces local neuronal production of CGRP to improve bone-fracture healing in rats. Nat. Med. 2016, 22, 1160-1169. [CrossRef] [PubMed]

7. Niinomi, M.; Nakai, M. Titanium-Based Biomaterials for Preventing Stress Shielding between Implant Devices and Bone. Int. J. Biomater. 2011, 2011, 836587. [CrossRef]

8. Zimmerli, W.; Moser, C. Pathogenesis and treatment concepts of orthopaedic biofilm infections. FEMS Immunol. Med. Microbiol. 2012, 65, 158-168. [CrossRef]

9. Bozic, K.J.; Kurtz, S.M.; Lau, E.; Ong, K.; Chiu, V.; Vail, T.P.; Rubash, H.E.; Berry, D.J. The epidemiology of revision total knee arthroplasty in the United States. Clin. Orthop. Relat. Res. 2010, 468, 45-51. [CrossRef]

10. Gao, P.; Fan, B.; Yu, X.; Liu, W.; Wu, J.; Shi, L.; Yang, D.; Tan, L.; Wan, P.; Hao, Y.; et al. Biofunctional magnesium coated Ti6Al4V scaffold enhances osteogenesis and angiogenesis in vitro and in vivo for orthopedic application. Bioact. Mater. 2020, 5, 680-693. [CrossRef]

11. Galli, S.; Naito, Y.; Karlsson, J.; He, W.; Andersson, M.; Wennerberg, A.; Jimbo, R. Osteoconductive Potential of Mesoporous Titania Implant Surfaces Loaded with Magnesium: An Experimental Study in the Rabbit. Clin. Implant Dent. Relat. Res. 2015, 17, 1048-1059. [CrossRef]

12. Galli, S.; Naito, Y.; Karlsson, J.; He, W.; Miyamoto, I.; Xue, Y.; Andersson, M.; Mustafa, K.; Wennerberg, A.; Jimbo, R. Local release of magnesium from mesoporous $\mathrm{TiO} 2$ coatings stimulates the peri-implant expression of osteogenic markers and improves osteoconductivity in vivo. Acta Biomater. 2014, 10, 5193-5201. [CrossRef] [PubMed]

13. Tian, L.; Tang, N.; Ngai, T.; Wu, C.; Ruan, Y.; Huang, L.; Qin, L. Hybrid fracture fixation systems developed for orthopaedic applications: A general review. J. Orthop. Transl. 2019, 16, 1-13. [CrossRef] [PubMed]

14. Tian, L.; Sheng, Y.; Huang, L.; Chow, D.H.; Chau, W.H.; Tang, N.; Ngai, T.; Wu, C.; Lu, J.; Qin, L. An innovative Mg/Ti hybrid fixation system developed for fracture fixation and healing enhancement at load-bearing skeletal site. Biomaterials 2018, 180, 173-183. [CrossRef]

15. Murray, J.L. (Ed.) Mg-Ti (Magnesium-Titanium), 2nd ed.; ASM International: Novelty, OH, USA, 1990; Volume 3, pp. $2559-2560$.

16. Esen, Z.; Dikici, B.; Duygulu, O.; Dericioglu, A.F. Titanium-magnesium based composites: Mechanical properties and in-vitro corrosion response in Ringer's solution. Mater. Sci. Eng. A 2013, 573, 119-126. [CrossRef]

17. Hou, P.; Han, P.; Zhao, C.; Wu, H.; Ni, J.; Zhang, S.; Liu, J.; Zhang, Y.; Xu, H.; Cheng, P.; et al. Accelerating Corrosion of Pure Magnesium Co-implanted with Titanium in Vivo. Sci. Rep. 2017, 7, 41924. [CrossRef]

18. Esen, Z.; Öcal, E.B.; Akkaya, A.; Gürçay, B.; Özcan, C.; Özgümüş, B.A.; Duygulu, Ö.; Dericioğlu, A.F. Corrosion behaviours of Ti6Al4V-Mg/Mg-Alloy composites. Corros. Sci. 2020, 166, 108470. [CrossRef]

19. Sherif, E.M.; AlHazaa, A.N.; Abdo, H.S. Manufacturing of Mg-Ti Couples at Different Heat Treatment Temperatures and Their Corrosion Behavior in Chloride Solutions. Materials 2019, 12, 1300. [CrossRef]

20. Liu, Y.; Chen, L.F.; Tang, H.P.; Liu, C.T.; Liu, B.; Huang, B.Y. Design of powder metallurgy titanium alloys and composites. Mater Sci. Eng. A 2006, 418, 25-35. [CrossRef]

21. Ye, H.Z.; Liu, X.Y.; Hong, H.P. Fabrication of metal matrix composites by metal injection molding-A review. J. Mater. Process. Technol. 2008, 200, 12-24. [CrossRef]

22. Wolff, M.; Ebel, T.; Dahms, M. Sintering of Magnesium. Adv. Eng. Mater. 2010, 12, 829-836. [CrossRef]

23. Wolff, M.; Schaper, J.; Suckert, M.; Dahms, M.; Feyerabend, F.; Ebel, T.; Willumeit-Römer, R.; Klassen, T. Metal Injection Molding (MIM) of Magnesium and Its Alloys. Metals 2016, 6, 118. [CrossRef]

24. Haramus, V.; Ebel, T.; Ramakrishnegowda, N.; Bußacker, S.; Schaper, J. Method for Producing a Metallic Implant. EP3524280A1, 8 January 2020. Available online: https:/ / patents.google.com/patent/EP3524280A1/en (accessed on 26 February 2021).

25. Su, Y.; Wang, L.; Luo, L.; Liu, X.; Guo, J.; Fu, H. Investigation of melt hydrogenation on the microstructure and deformation behavior of Ti-6Al-4V alloy. Int. J. Hydrogen Energy 2011, 36, 1027-1036. [CrossRef]

26. Shen, C.-C.; Wang, C.-M. Effects of hydrogen loading and type of titanium hydride on grain refinement and mechanical properties of Ti-6Al-4V. J. Alloys Compd. 2014, 601, 274-279. [CrossRef] 
27. Liang, C.H.; Jia, L.N.; Yuan, C.J.; Huang, N.B. Crevice Corrosion Behavior of CP Ti, Ti-6Al-4V Alloy and Ti-Ni Shape Memory Alloy in Artificial Body Fluids. Rare Met. Mater. Eng. 2015, 44, 781-785.

28. Sun, P.; Fang, Z.Z.; Koopman, M.; Paramore, J.; Chandran, K.S.R.; Ren, Y.; Lu, J. An experimental study of the (Ti-6Al-4V)-xH phase diagram using in situ synchrotron XRD and TGA/DSC techniques. Acta Mater. 2015, 84, 29-41. [CrossRef]

29. Lenning, G.A.; Craighead, C.M.; Jaffee, R.I. Constitution and mechanical properties of titanium-hydrogen alloys. JOM 1954, 6, 367-376. [CrossRef]

30. ASTM. Standard Specification for Titanium and Titanium Alloy Bars and Billets; ASTM: West Consensehocken, PA, USA, 2009.

31. Liu, H.J.; Zhou, L.; Liu, P.; Liu, Q.W. Microstructural evolution and hydride precipitation mechanism in hydrogenated Ti-6Al-4V alloy. Int. J. Hydrogen Energy 2009, 34, 9596-9602. [CrossRef]

32. Luppo, M.I.; Politi, A.; Vigna, G. Hydrides in $\alpha$-Ti: Characterization and effect of applied external stresses. Acta Mater. 2005, 53, 4987-4996. [CrossRef]

33. Manchester, F.D.; San-Martinm, A. H-Ti (hydrogen-titanium). In Phase Diagrams of Binary Hydrogen Alloys; ASM International: Materials Park, OH, USA, 2000; p. 238.

34. Fukai, Y. Phase-Diagrams of transition metal-hydrogen systems. J. Jpn. Inst. Met. 1991, 55, 17-21. [CrossRef]

35. Zhang, J.; He, H.; Tang, Y.; Ji, X.; Wang, H. Advanced Materials Prepared via Metallic Reduction Reactions for Electrochemical Energy Storage. Small Methods 2020, 4, 2000613. [CrossRef]

36. Hoche, D.; Blawert, C.; Lamaka, S.V.; Scharnagl, N.; Mendis, C.; Zheludkevich, M.L. The effect of iron re-deposition on the corrosion of impurity-containing magnesium. Phys. Chem. Chem. Phys. 2016, 18, 1279-1291. [CrossRef]

37. Wurger, T.; Feiler, C.; Vonbun-Feldbauer, G.B.; Zheludkevich, M.L.; Meissner, R.H. A first-principles analysis of the charge transfer in magnesium corrosion. Sci. Rep. 2020, 10, 15006. [CrossRef] [PubMed]

38. Zu, D.; Xu, Z.; Zhang, A.; Wang, H.; Wei, H.; Ou, G.; Huang, K.; Zhang, R.; Li, L.; Hu, S.; et al. Room temperature Mg reduction of TiO2: Formation mechanism and application in photocatalysis. Chem. Commun. 2019, 55, 7675-7678. [CrossRef]

39. Peng, P.-W.; Ou, K.-L.; Lin, H.-C.; Pan, Y.-N.; Wang, C.-H. Effect of electrical-discharging on formation of nanoporous biocompatible layer on titanium. J. Alloys Compd. 2010, 492, 625-630. [CrossRef]

40. Ban, S.; Iwaya, Y.; Kono, H.; Sato, H. Surface modification of titanium by etching in concentrated sulfuric acid. Dent. Mater. 2006, 22, 1115-1120. [CrossRef] [PubMed]

41. Ibrahim, M.; Yu, X.; Tan, L.; Yang, K. Influence of Strontium phosphate Coating on the Degradation of Physical Vapor Deposition Sprayed Mg Coating on Ti6Al4V Substrate to Promote Bone Tissue Healing. Front. Mater. 2020, 7, 3240. [CrossRef] 